\title{
Promoting the Residents' Sense of Belonging in Housing Design
}

\author{
Zohreh Yousefi ${ }^{1}$, Seyed-Bagher Hosseini², \\ Seyed-Abbas Yazdanfar², Saeid Norouzian-Maleki ${ }^{3}$ \\ ${ }^{1}$ Msc. student, ${ }^{2}$ Associate professor, \\ School of Architecture and Environmental Design, \\ Iran University of Science and Technology, Iran \\ ${ }^{3}$ Assistant professor, Faculty of Architecture and Urban Planning, \\ Shahid Beheshti University, Tehran, Iran \\ yousefi_zohreh@yahoo.com
}

\begin{abstract}
Today, poor performance in old residential contexts in terms of memorable visual elements reduce the residents' sense of belonging. The study used a combination of qualitative and quantitative research methods. To meet the needs of residents, a questionnaire was distributed among twenty-five experts. Data analysis was performed using fuzzy logic to calculate the weight of each criterion of hierarchical fuzzy (FAHP). According to the findings, the largest weight belonged to social interaction (0.288), physical $(0.205)$ and dependence $(0.179)$. The results showed that social interaction is imperative in increasing the residents' sense of belonging.
\end{abstract}

Keywords: Housing, Place, Sense of belonging, FAHP

eISSN: 2398-4295 @ 2017. The Authors. Published for AMER ABRA by e-International Publishing House, Ltd., UK. This is an open access article under the CC BY-NC-ND license (http://creativecommons.org/licenses/by-ncnd/4.0/). Peer-review under responsibility of AMER (Association of Malaysian Environment-Behaviour Researchers), ABRA (Association of Behavioural Researchers on Asians) and CE-Bs (Centre for EnvironmentBehaviour Studies), Faculty of Architecture, Planning \& Surveying, UniversitiTeknologi MARA, Malaysia. https://doi.org/10.21834/ajbes.v2i5.47 


\subsection{Introduction}

Today, in the old residential areas, factors such as lack of adequate access to vehicles and pavements, overshadow memorable elements in the neighborhood and ignoring open spaces such as courtyards has decreased residents' interactions, sense of belonging and satisfaction. This incompatibility of old housing with the demands and needs of users has become a serious problem. House renovation is not in agreement with the concepts and principles of today's housing and this mismatch has caused the texture to be evacuated. Texture has helped human to make their existence meaningful, and it is only alive with human and their sense of belonging. The overall goal of this study is to return residence to the existing homes in one of the old areas of Tehran (Zargandeh) and to increase the residents' sense of belonging by providing facilities and services, satisfaction enhancement, transparency of the space, suitability and visual fitness of the houses with the current context of the neighborhood. The present study seeks to answer the following questions: What are the main factors affecting the residents' sense of belonging in Zargandeh? What are the most important strategies for designing housing templates to increase the residents' sense of belonging?

\subsection{Literature Review}

The old residential area is a part of the city that has lost its identity due to physical or performance weakness, and cannot develop a sense of belonging among its residents. Residential textures wearing in the urban context affect the social and economic activities and leads to a severe decrease in the quality of urban life as well as environmental quality. To get a sense of belonging in the old housing texture, it is necessary to examine the concept of place, human relationship with the place, identity and sense of the site. A place is a space compatible with meaning (Lewicka, 2011). It is a space that is significant for an individuals or a group of individuals. Based on phenomenological definition, it can be argued that the nature of "placing" is specifically against the most general concept of "spacing" (Knez, 2014). Therefore, building a meaningful place in the old residential context makes it remarkable and significant for its residents. What architects create is a potential environment for human behavior and what the person admires is the environment affecting him (Lang, 2007). Cross (2001) classified the relationship between humans and place into six groups of biological, psychological, ideological, narrative, commodity and attachment. The concept of identity of a place means its characteristics that distinguish the place from other places and its continuity over time (Lewika, 2008; Finney\& Jivraj, 2013). There are two basic approaches in the field of phenomenology and psychology to the definition sense of a place. The phenomenological approach is dominant in the literature (Stedman, 2003). The Physical perspective of environmental psychology, and emotional interaction between humans and a place are studied as a sense of place in order to achieve greater satisfaction with residence, in addition to strengthening the sense of belonging, attachment to the 
space, security, identity and authenticity in humans (Haywood, 2014). Place includes material and non-material aspects, and by the feeling that it creates for its inhabitants, a kind of belonging to the place is created in people which lead to the identity of the place. This spiritual force is called a sense of setting (Semken \& Freeman, 2008). In the science of sociology, the emphasis is put on how symbolic meaning of place affects the social context of human relationships (Nicotera, 2007; Trentelman, 2009). A sense of affection to the place appears from individual and social perceptions, habits and experiences of people (Jiven \& Larkham, 2003; Manzo, Perkins 2006; Scannell \& Gifford, 2010). A sense of attachment to place has attracted the interest of anthropologists and sociologists to study the relationship between humans and holy places (Mihaylov \& Perkins, 2013). Due to rapid changes in modern life and coordination and harmony with modern life attachment to places has found more relevance in today's studies (Gifford et al., 2009). Components of the sense of attachment including "physical environment", "users" and "attachment process" and the type of interaction and relationship between the individual and the place are also important in the study of attachment (Gifford, 2009; Stedman, 2006). Lewicka (2011) stated that progress mainly happened in the application of the concept of place attachment to levels other than neighborhood and permanent residence, by introducing a new dimension of attachment to place (paying attention to the physical aspect of the environment). This study found the positive role of the meaning of place and changes in the environment that lead to an increase in the quality. This study seeks to determine the importance of selected variables to enhance the sense of attachment among the residents.

Table 1- The variables to enhance the sense of attachment to the residents

\begin{tabular}{llll}
\hline Criteria & Sub A & Sub B & Sub C \\
\hline $\begin{array}{l}\text { Dependence } \\
\text { Differentiation }\end{array}$ & Residence time & Satisfaction & Ownership \\
Meaning & Continuity & Identity \\
Social interaction & Personal characteristics & Level relationship & Quality of interaction \\
Physical & Solidarity & Legibility & View \\
\hline
\end{tabular}

(Source: Authors)

\subsection{Methodology}

To assess the sense of attachment to residents of the old residential area, anthropological studies were conducted with qualitative and survey method. The case of the study was Zargandeh. The neighborhoods have an area of 129 acres in Tehran. Areas in the central and northern parts of the place and eastern, southern and western parts were checked regularly. Zargandeh formed has been formed since 1951 in urban areas. Residents are of low economic status. Neighborhoods have an old texture. Therefore, the research was conducted by a combination of qualitative and quantitative methods. First, semi-structured interviews were conducted with residents. Based on the results of the literature review and 
interviews a questionnaire with 25 items was distributed among twenty-five experts on architecture and the collected data were analyzed using the FAHP.

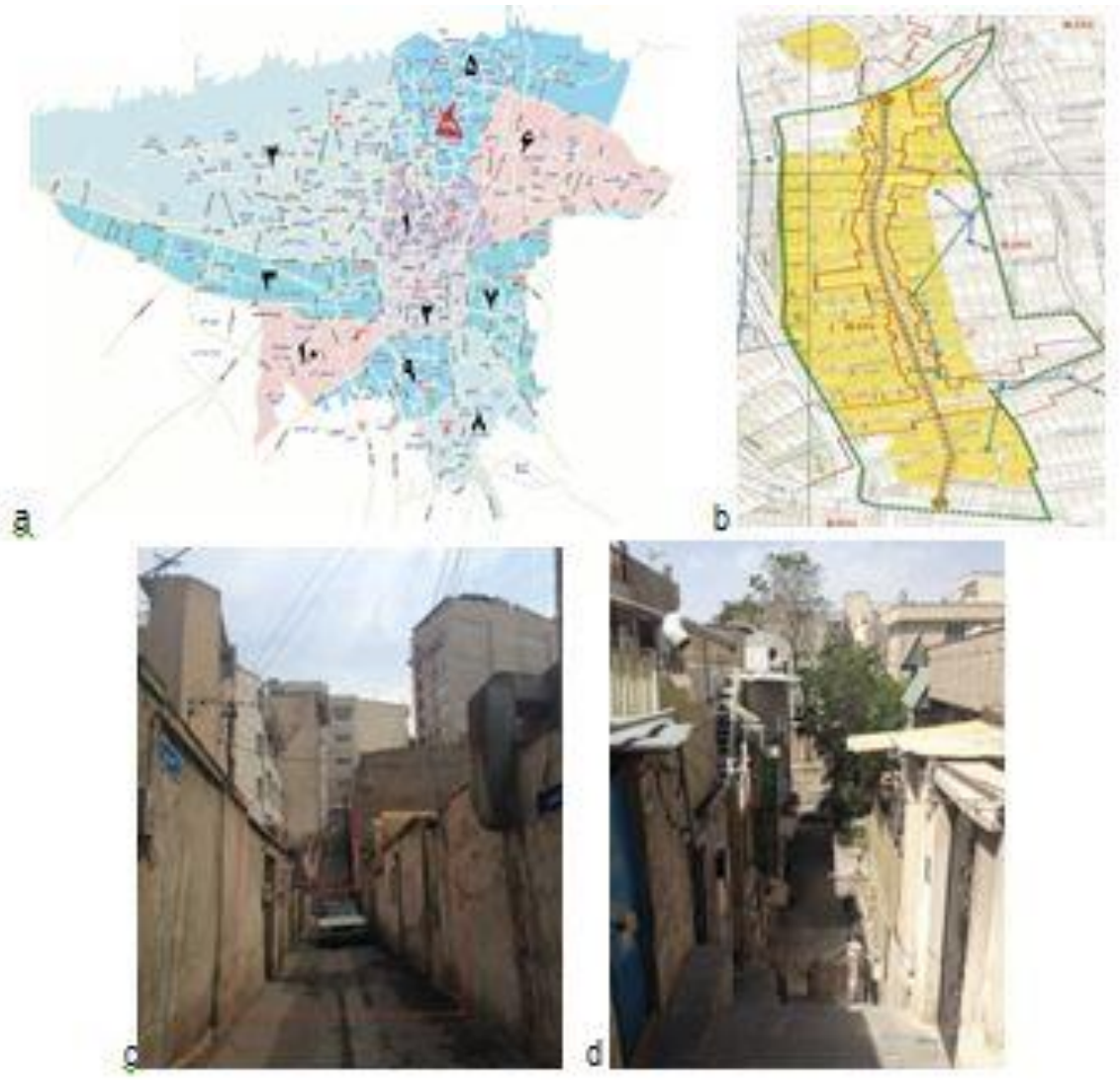

Fig. 1. (a) The site of the Zargandeh in Tehran; (b) limit of the old texture in Zargandeh; (c) The different ratios of Width/Height; (d) A view of the alley

(Source: Authors)

\subsection{Fuzzy Analytical Hierarchy Process (FAHP)}

Since the uncertainty is one of the most common characteristics of decision-making issues, FAHP method has been created to meet these problems. This approach lets decisionmakers express their limit priority to fuzzy numbers (Meixner, 2012). A method was presented by Chang named Extant Analysis Method (Zhu, Jing, Chang, 1999) the steps of which are described below: 
A- Hierarchical Diagram For selection criteria for the decision, a hierarchical chart must be drawn.

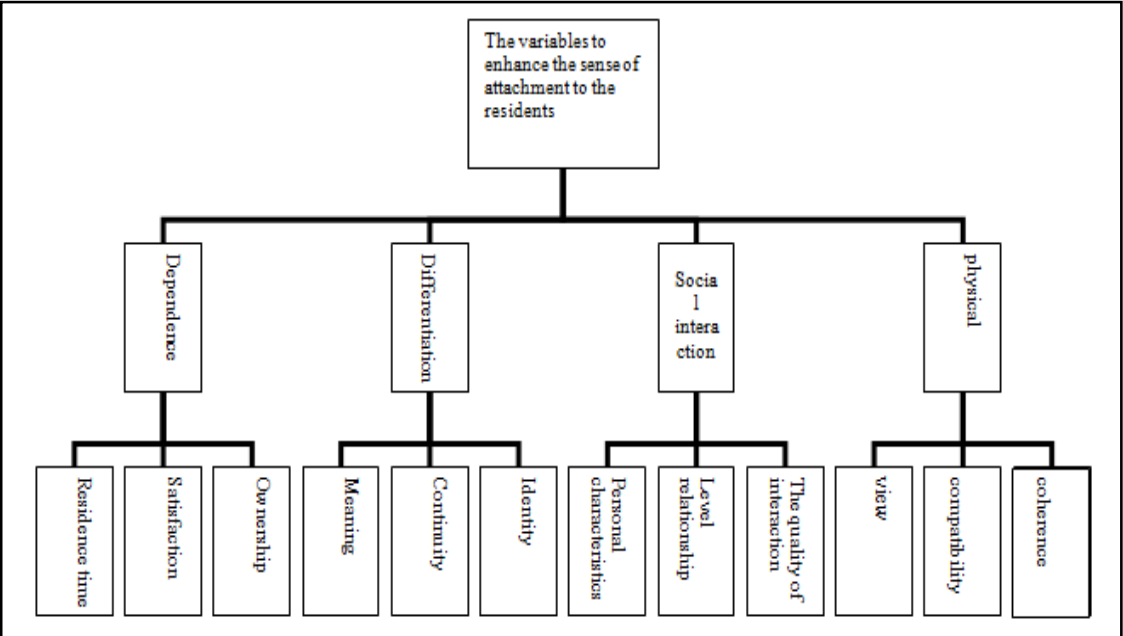

Figure 1- Hierarchical Diagram, Selection criteria affecting residents' sense of attachment (Source: Authors)

B- The definition of fuzzy numbers to make paired comparisons

For the purpose of making comparisons, we need to define fuzzy numbers and fuzzy. An example of these is given in Table 2.

Table 2- Fuzzy Numbers and Scales

\begin{tabular}{lll}
\hline A level of fuzzy triangular & Fuzzy value & Preference \\
\hline$(1,1,1)$ & 1 & Exactly equal importance \\
$(2 / 1,1,2 / 3)$ & 2 & The importance too weak \\
$(1,2 / 3,2)$ & 3 & The importance weak \\
$(2 / 3,2,2 / 5)$ & 4 & The importance firm \\
$(2,2 / 5,3)$ & 5 & The importance, so high \\
$(2 / 5,3,2 / 7)$ & 6 & Absolutely importance \\
\hline
\end{tabular}

(Source: Meixner, 2012)

C- Paired comparison matrices using fuzzy numbers

Paired comparison matrix (A) contains the definitions of fuzzy numbers as follows. 
$\widetilde{\mathrm{A}}=\left[\begin{array}{cccc}1 & \widetilde{\mathrm{a}_{12}} & \cdots & \widetilde{\mathrm{a}_{1 \mathrm{n}}} \\ \widetilde{\mathrm{a}_{21}} & 1 & \cdots & \widetilde{\mathrm{a}_{2 \mathrm{n}}} \\ \vdots & \vdots & \ddots & \vdots \\ \widetilde{\mathrm{a}_{\mathrm{n} 1}} & \widetilde{\mathrm{a}_{\mathrm{n} 2}} & \cdots & 1\end{array}\right]$

$D-S_{i}$ is calculated by the following equation for each of the paired comparison matrix rows each of which is a triangular fuzzy number.

$S_{i}=\sum_{j=1}^{m} M_{g i}^{j} \times\left[\sum_{i=1}^{n} \sum_{j=1}^{m} M_{g i}^{j}\right]^{-1}$

E- Calculation of the magnitude of Si against each other

Totally, the size of Si against $\mathrm{Si}$ is obtained by the following equation:

$$
V\left(S_{i} \geq S_{j}\right)=\operatorname{hgt}\left(S_{i} \cap S_{j}\right)=\mu_{s_{i}}(d)= \begin{cases}1 & \text { if } m_{i} \geq m_{j} \\ 0 & \text { if } l_{j} \geq u_{i} \\ \frac{l_{j}-u_{i}}{\left(m_{i}-u_{i}\right)-\left(m_{j}-u_{j}\right)} & \text { otherwise }\end{cases}
$$

F- Measurement of criteria and options in the paired comparison matrix

To calculate non-normalized weight of criterion the magnitude of a triangular fuzzy number compared with other triangular fuzzy numbers was calculated and to calculate the minimum size, representing non-normalized weight of criteria, the following equation was used:

$$
\begin{aligned}
& \mathrm{d}^{\prime}\left(\mathrm{A}_{\mathrm{i}}\right)=\operatorname{Min} \mathrm{V}\left(\mathrm{S}_{\mathrm{i}} \geq \mathrm{S}_{\mathrm{k}}\right) \quad \mathrm{k}=1,2, \ldots, \mathrm{n}, \quad \mathrm{k} \neq \mathrm{i} \\
& \mathrm{G} \text { - Calculation of final weight vector }
\end{aligned}
$$

The final weight vector was obtained by normalizing the weight vector of criterion. Formula 9 were used to derive the final weight vector.

$W=\left(d\left(A_{1}\right), d\left(A_{2}\right), \ldots, d\left(A_{n}\right)\right)^{t}$

\subsection{Results and Discussions}

The main criteria and sub-criteria were provided for experts in the form of a questionnaire aiming at making comparisons. First, the six main criteria were mutually compared. Then the sub-criteria of the main criteria were mutually correlated. To calculate the weight of each criterion, a paired comparison matrix of criteria was formed. To fill these tables, the experts examined the criterion of each level. According to their oral judgment, for each of the six states of Table 1, they put related fuzzy numbers in the tables of paired comparison. After completing the tables by the experts, the weight of criteria, at each level, was calculated using FAHP. The weights were measured through programs written in MATLAB software in which the pressure in each level was specified by entering data into a paired comparison matrix of criterion. The final weight of each criterion in each level was obtained by taking the 
arithmetic mean of the existing weights. The result of these weights is an average of the experts' results.

Table 3- Paired Criterions comparison

\begin{tabular}{lllll}
\hline & Dependence & Differentiation & $\begin{array}{l}\text { Social } \\
\text { interaction }\end{array}$ & physical \\
\hline Dependence & $(1,1,1)$ & $(2 / 3,2,2 / 5)$ & $(2,2 / 5,3)$ & $(1,2 / 3,2)$ \\
Differentiation & & $(1,1,1)$ & $(2 / 1,1,2 / 3)$ & $(2 / 1,1,2 / 3)$ \\
Social interaction & & $(1,1,1)$ & $(2 / 5,3,2 / 7)$ \\
physical & & & $(1,1,1)$ \\
\hline
\end{tabular}

(Source: Authors)

In paired criteria of dependence with other criteria, the social interaction $(2,2 / 5,3)$ is more important than the differentiation $(2 / 3,2,2 / 5)$ and physical $(1,2 / 3,2)$. The experts' further measures were a sense of belonging, social interaction, dependence, physical and differentiation.

Table 4- Paired comparison sub-Criterions of Dependence

\begin{tabular}{cccc}
\hline & $\begin{array}{c}\text { Residence } \\
\text { time }\end{array}$ & Satisfaction & Ownership \\
\hline $\begin{array}{c}\text { Residence } \\
\text { tims } \\
\text { Satisfaction }\end{array}$ & $(1,1,1)$ & $(1,2 / 3,2 / 7)$ & $(2 / 1,1,2 / 3)$ \\
Ownership & & $(1,1,1)$ & $(2 / 5,3,2 / 7)$ \\
\hline
\end{tabular}

(Source: Authors)

In paired sub-criteria of residence time with another sub-criteria, the satisfaction $(1,2 / 3,2 / 7)$ is more important than the ownership $(2 / 1,1,2 / 3)$. According to these experts, the subcriteria for dependence, satisfaction is more important than the residence and ownership.

Table 5- Paired comparison sub-Criterions of Differentiation

\begin{tabular}{lccc}
\hline & Meaning & Continuity & Identity \\
\hline Meaning & $(1,1,1)$ & $(2 / 5,3,2 / 7)$ & $(2,2 / 5,3)$ \\
Continuity & & $(1,1,1)$ & $(2 / 3,2,2 / 5)$ \\
Identity & & & $(1,1,1)$ \\
\hline
\end{tabular}

(Source: Authors) 
In paired sub-criteria of meaning with another sub-criteria, the identity $(2,2 / 5,3)$ is more important than the continuity $(2 / 5,3,2 / 7)$. According to these experts, the sub-criteria for differentiation, identity is more important than the continuity and meaning.

\begin{tabular}{|c|c|c|c|}
\hline & $\begin{array}{l}\text { Personal } \\
\text { characteristics }\end{array}$ & $\begin{array}{l}\text { Level } \\
\text { relationship }\end{array}$ & $\begin{array}{l}\text { Quality of } \\
\text { interaction }\end{array}$ \\
\hline $\begin{array}{l}\text { Personal } \\
\text { characteristics }\end{array}$ & $(1,1,1)$ & $(2 / 5,3,2 / 7)$ & $(2 / 1,1,2 / 3)$ \\
\hline $\begin{array}{l}\text { Level } \\
\text { relationship }\end{array}$ & & $(1,1,1)$ & $(2 / 3,2,2 / 5)$ \\
\hline $\begin{array}{l}\text { The quality of } \\
\text { interaction }\end{array}$ & & & $(1,1,1)$ \\
\hline
\end{tabular}

In paired sub-criteria of personal characteristics with another sub-criteria, the level relationship $(2 / 5,3,2 / 7)$ is more important than the quality of interaction $(2 / 1,1,2 / 3)$. According to these experts, the sub-criteria for social interaction, the level relationship is more important than the quality of interaction and personal characteristics.

\begin{tabular}{|c|c|c|c|}
\hline & View & Compatibility & Coherence \\
\hline View & $(1,1,1)$ & $(2 / 5,3,2 / 7)$ & $(2,2 / 5,3)$ \\
\hline Compatibility & & $(1,1,1)$ & $(1,2 / 3,2)$ \\
\hline Coherence & & & $(1,1,1)$ \\
\hline
\end{tabular}

(Source: Authors)

In paired sub-criteria of view with other sub-criteria, the coherence $(2,2 / 5,3)$ is more important than the compatibility $(2 / 5,3,2 / 7)$. According to these experts, the sub-criteria for physical coherence is more important than the compatibility and view.

In the attachment weight of criterion, in the order of preference, sub-criteria of satisfaction, $w=0.555$ residence time, $w=0.240$ and ownership, $w=0.204$ are preferable. As shown in Table 8, among different sub-criteria, in the order of preference, sub-criteria of identity, meaning and continuity are preferred and identity has more weight $(w=0.525)$. As for the final weight of the sub-criteria of social relations, in the order of priority, the subcriteria of interaction quality, $W=0.459$ personal characteristics, $W=0.273$ and level of relationship, $W=0.266$ were prioritized. Therefore, in social relations, quality of interaction plays a significant role. With regard to the weight of physical sub-criteria, in the order of 
preference, sub-criteria of coherence, $w=0.263$ compatibility, $w=0.163$ and view, $w=0.135$ are preferred.

Table 8- The final weight of the sub-criteria

\begin{tabular}{|c|c|c|c|c|c|c|c|}
\hline $\begin{array}{c}\text { physic } \\
\text { al }\end{array}$ & $\begin{array}{c}\text { Weigh } \\
t\end{array}$ & $\begin{array}{c}\text { Social } \\
\text { intera } \\
\text { ction }\end{array}$ & $\begin{array}{l}\text { Wei } \\
\text { ghts }\end{array}$ & $\begin{array}{c}\text { Diffe } \\
\text { renti } \\
\text { atio } \\
n\end{array}$ & $\begin{array}{l}\text { Wei } \\
\text { ghts }\end{array}$ & $\begin{array}{c}\text { Depend } \\
\text { ence }\end{array}$ & Weights \\
\hline $\begin{array}{l}\text { coher } \\
\text { ence }\end{array}$ & $\begin{array}{c}w=0 . \\
263\end{array}$ & $\begin{array}{l}\text { Perso } \\
\text { nal } \\
\text { chara } \\
\text { cterist } \\
\text { ics }\end{array}$ & $\begin{array}{c}W=0 \\
273\end{array}$ & $\begin{array}{c}\text { Iden } \\
\text { tity }\end{array}$ & $\begin{array}{c}W=0 \\
525\end{array}$ & $\begin{array}{c}\text { Owners } \\
\text { hip }\end{array}$ & $\begin{array}{c}W=0 . \\
204\end{array}$ \\
\hline $\begin{array}{c}\text { Comp } \\
\text { atibilit } \\
y\end{array}$ & $\begin{array}{c}w=0 . \\
163\end{array}$ & $\begin{array}{l}\text { Level } \\
\text { relatio } \\
\text { nship }\end{array}$ & $\begin{array}{c}W=0 \\
266\end{array}$ & $\begin{array}{c}\text { Cont } \\
\text { inuit } \\
y\end{array}$ & $\begin{array}{c}W=0 \\
168\end{array}$ & $\begin{array}{c}\text { Satisfac } \\
\text { tion }\end{array}$ & $\begin{array}{c}W=0 . \\
555\end{array}$ \\
\hline view & $\begin{array}{c}w=0 . \\
135\end{array}$ & $\begin{array}{l}\text { The } \\
\text { qualit } \\
\text { y of } \\
\text { intera } \\
\text { ction }\end{array}$ & $\begin{array}{c}W=0 \\
459\end{array}$ & $\begin{array}{l}\text { Mea } \\
\text { ning }\end{array}$ & $\begin{array}{c}W=0 \\
305\end{array}$ & $\begin{array}{c}\text { Reside } \\
\text { nce } \\
\text { time }\end{array}$ & $\begin{array}{c}W=0 . \\
240\end{array}$ \\
\hline
\end{tabular}

(Source: Authors)

Table 9- The final weight in the selection criterion to promote a sense of belonging residents

\begin{tabular}{cccc}
\hline Social interaction & Dependence & Physical & Differentiation \\
\hline 0.288 & 0.205 & 0.179 & 0.155 \\
\hline \multicolumn{4}{c}{ (Source: Authors) }
\end{tabular}

The weights of criteria were as follows: the criterion of social interaction has a weight of 0.288 , the criterion of dependence has a weight of 0.205 , the criterion of form has a weight of 0.179 , and the criterion of differentiation weighs 0.155 . Interestingly, social interaction weighed 0.288 that has more weight than the other criterions. Thus, it is plausible to say by taking social interaction and priorities into consideration and considering sub-criteria of quality, interaction in social ties, highlighting the significant elements in the residential context, it is possible to promote the residents' sense of attachment. 


\subsection{Conclusion}

The results show that the most important criterion for priority is social interactions $(0.288)$, dependence (0.205), physical (0.179), differentiation (0.155). According to the findings, more attention should be paid to social interaction $(w=0.288)$. We know that the old context requires place efficiency and quality of interaction between residents. Social interaction is affected by the activities, culture and communication and social interactions of residents, which brings about mass memory, place efficiency, and the presence of residents in the residential textures and enhances the sense of attachment of the residents. The second measure in the sense of belonging is an attachment that can be strengthened concerning the satisfaction of the inhabitants. The third important action to increase the sense of belonging is physical elements. Also by facilitating activities in agreement with the needs of residents, more social connections occur in the place and thus their sense of belonging to a place increases. The dependence and physical are other factors affecting the residents' sense of belonging. Differentiation has less impact on the sense of belonging among residents in the old texture. Since the residents are low-income groups of society, it is necessary to design their homes in the same area taking into consideration the element of the courtyard and create a space for interactions among residents. For the neighborhood and homes, a green space and a meeting space should be considered. Considering green space per capita in the house courtyard, and the possibility of a view of the yard by the private, semi-private and public spaces are also important. Courtyard homes not overlooking the adjacent units must be available for residents to increase their sense of belonging to their homes.

\section{References}

Cross, J. (2001). What is Sense of place? 12th Headwaters Conference. November 2-4 Western State College.

Finney, N. \& Jivraj, S. (2013). Ethnic group population change and neighbourhood belonging. Urban Studies, 50(16), 3323-3341.

Gifford, R., Scannell, L., Kormos, C., Smolova, L., Biel, A., Boncu, S., et al. (2009). Temporal pessimism and spatial optimism in environmental assessment: An 18-nation study. Journal of Environmental Psychology, 29(1), 112.

Haywood, B. K. (2014). A "sense of place" in public participation in scientific research. Science Education, 98(1), 64-83.

Jive'n, G., \& Larkham, P. J. (2003). Sense of place, authenticity and character: a commentary. Journal of Urban Design, 8(1), 67-81.

Knez, I. (2014). Place and the self: An autobiographical memory synthesis. Philosophical Psychology, 27(2), 164192.

Lang, J. (2007). The Role of Behavioral Sciences in Environmental Design. 
Lewicka, M. (2008). Place attachment, place identity and place memory: Restoring the forgotten city past. Journal of Environmental Psychology, 28(3), 209-231.

Lewicka, M. (2011). Place attachment: How far have we come in the last 40 years? Journal of Environmental Psychology 31, 207-230.

Manzo, L. C., \& Perkins, D. D. (2006). Finding common ground: The importance of place attachment to community participation and planning. Journal of Planning Literature, 20, 335-350.

Meixner, O. (2012). Fuzzy AHP group decision analysis and application for the evaluation of energy sources. Institute of marketing, Vienna, Austria.

Mihaylov, N., \& Perkins, D. D. (2013). Community place attachment and its role in social capital development (pp. 61-74). Routledge: New York, NY, USA.

Nicotera, N. (2007). Measuring neighborhood: A conundrum for human services researchers and practitioners. American Journal of Community Psychology, 40, $26 \mathrm{e} 51$.

Proshansky, H. M. (1983). Place-Identity: Physical World Socialization of the Self. Journal of Environmental Psychology, 3, 57-83.

Scannell, L., \& Gifford, R. (2010). Defining place attachment: A tripartite organizing framework. Journal of Environmental Psychology, 30(1), 1-10.

Semken, S \& Freeman, C. B. (2008). Sense of Place in the Practice and Assessment of Place-Based Science Teaching, Science Education 92, pp: 1042-1058. DOI 10.1002/sce.20279.

Stedman, R. C. (2003). Is it really just a social construction?: The contribution of the physical environment to sense of place. Society and Natural Resources, 16(8), 671-685.

Stedman, R. C. (2006). Understanding place attachment among second home owners. American Behavioral Scientist, 50(2), 187-205.

Trentelman, C. K. (2009). Place attachment and community attachment: A primer grounded in the lived experience of a community sociologist. Society and Natural Resources, 22, 191-210.

Zhu, K. J., Jing, Y., Chang, D. Y. (1999). Theory and Methodology, A discussion on extent analysis method and applications of fuzzy AHP. European journal of operational research, 116, pp. 450-456. 